\title{
Sustainability Through the Market - the Impacts of Sustainable Supply Chain Management: Introduction
}

\author{
Walter J. V. Vermeulen'* and Stefan Seuring ${ }^{2}$ \\ ${ }^{1}$ Copernicus Institute for Sustainable Development and Innovation, Utrecht University, Netherlands \\ ${ }^{2}$ Department of International Management, University of Kassel, Germany
}

Keywords: sustainability; supply chain management; supply chain governance; certification; fair trade; organic agricultural products

W

ITH ENVIRONMENTAL PROTECTION GAINING ITS PROMINENCE ON THE POLITICAL AGENDA IN THE LATE 196OS and I970s, producers of commodities originally were addressed on the externalities connected to their products by national and local governments, with regulative approaches. Meanwhile, environmental NGOs and peers in the public debate have been pushing politicians and governments to improve the effectiveness of these policies. Starting in the late I980s and early I990s we have been witnessing a fast and substantial shift away from this classical, adversarial image of environmental politics, in at least four ways. First, environmental policies have been embedded in the broader concept of sustainable development, including issues of community responsibility of producers and promotion of fair distribution of the benefits of nature's rich resources. Second, individual producers, as production units in the larger social system of a commodity chain, increasingly are addressed as being responsible for their societal impacts. Third, this responsibility is shared with business partners along the whole supply chain (as described in the concepts of business management) or the whole life cycle of their products (as described in the concepts of environmental sciences). Finally, this message is not one just received by producers from government agencies, but increasingly directly from actors from civil society and customers.

Businesses have learned to work together with these actors and increasingly have internalized the concepts of sustainable development, life cycle management and accounting for corporate responsibility in their own value sets. The state dominated adversarial environmental politics have increasingly been replaced (or supplemented) by the model of sustainability through the market, where businesses and NGOs focus their efforts on implementing diverse forms of sustainable supply chain management and joint governance.

With this development, new schools of research and knowledge have emerged in the field of sustainable supply chain management (SSCM) and sustainable supply chain governance (SSCG), first in support of businesses taking up their active role in their supply chains: communicating about their 'joint environmental (and later socio-ethical) impacts' throughout the supply chain and developing strategies to improve them. This could either be taken up in a collaborative mode or by applying their market power. In either case, it usually includes green product (re)development as well as selecting suppliers that can meet the newly added sustainability requirements, often specified in environmental and social standards (Seuring and Müller, 2008b). Key topics also include striving for an extended sustainability performance, where trade-offs among the three dimensions of sustainability only result if efficiency frontiers are reached (Seuring and Müller, 2008a).

*Correspondence to: Walter J. V. Vermeulen, Copernicus Institute for Sustainable Development and Innovation, Utrecht University, The Netherlands. E-mail: w.vermeulen@geo.uu.nl 
In the last decade this development has been gaining speed. After an initial experimentation phase with individual frontrunner companies and sustainable entrepreneurs developing niche markets for Fair Trade and other sustainable (organic) products, in practice we have been entering a new phase of mainstream market activity in this field. This is also reflected in new research directions, focussing on the collaboration of multiple actors in addressing sustainability in full supply chains: the governance of (often world wide) supply chains.

The history of global sustainable supply chain governance started with small 'enlightened' entrepreneurs, often with a history in civil society, starting at first to bypass these dominant mainstream value chains. Fair trade initiatives started to create new and shorter value chains, more directly linking small producers in developing countries with western consumers, first in the late I970s and I980s. For this, new cooperatives were created and new distribution systems in countries such as Finland, Belgium, Germany and The Netherlands (world shops, green shops etc.). In the same way, trade in organic products has been organized in separate value chains, bypassing mainstream firms. In both cases control systems for securing quality, related to both product quality and environmental and social responsibility throughout the value chain, have been developed and implemented (such as Max Havelaar and EKO), including better prices for small farmers in developing countries (Ims and Jakobsen, 2006; Raynolds et al., 2007; Kilian et al., 2004; Davies, 2007; Bitzer et al., 2008).

With these approaches 'bioneers and ecopreneurs' (Schaltegger, 2002) in the market and civil society (NGOs) have been filling a 'regulation vacuum'. Western governments can hardly prevent the increasing shift of environmental impacts towards developing countries. This results from growing international trade. They are not entitled to address production conditions in developing countries. They have to walk the long route via supranational institutions (UN, OECD), with their weak implementation powers, and await effective implementation of UN agreements by national governments. The early examples of sustainable supply chain governance systems have not succeeded in conquering the mainstream of consumer markets (shares $<$ I-3\%).

However, this development is in full motion. We can distinguish three types of supply chain governance in this emerging practice: single firm approaches, joint product sector approaches and cross sector approaches (see for more detailed discussion Vermeulen, 2008).

Single firm approaches: first generation. Some individual firms have been taking the lead in improving both social and environmental conditions in all steps of the value chain (de Groene and Hermans, I998; Seuring, 2004; Vermeulen and Ras, 2006). This globe wide interaction is often a difficult job, as supply chains in most cases consist of large numbers of suppliers in various developing countries and such inquiries about social and environmental conditions are often misunderstood by suppliers and seen as unwelcome interference with their business. Yet, the early examples of Fair Trade and organic/green products, one of the key strategies in sustainable supply chain management (Seuring and Müller, 2008b), had already shown how improving production conditions can be achieved, also by organizing collectives of smallholders and creating independent export companies (Parrish et al., 2005; Kessler et al., 2003). Examples from more mainstream firms do also exist, as in the cases of the outdoor equipment producer Patagonia (Chouinard and Brown, 1997) or German mail-order business OTTO, which set up an additional organic cotton supply chain (Goldbach et al., 2003), while in another example the full business was redirected to organic products (Kogg, 2003). For individual firms this implies substantial extra transaction and control costs. One of the disadvantages of these individual firm approaches is the reliability of the businessto-business self-control and their claims on sustainable practices, which might easily be questioned by individual consumers or NGOs.

Joint product sector approaches: second generation. Joint approaches have been developed in different ways, which may reduce the problems of transaction costs and reliability. Originally, forms of eco-labelling assured independent control and have other advantages for individual firms in their interaction within the value chain. These systems for ecolabelling include environmental requirements in all relevant steps in the value chain applying the environmental life cycle approach (Guinee, 2002; Heijungs and Guinee, I992; Seuring and Müller, 2008a). Additionally, environmental and social standards are required before suppliers would be accepted as such (Seuring and Müller, $2008 \mathrm{~b}$ ). These are all early forms of value chain governance, mainly initiated by third parties (often representing state, environmental organizations and market) and including independent auditing. In the cases of governance with third party eco-labelling two new actors emerge in the producer-buyer relationship: the eco-label organization 
and the audit-organization. Well known examples would be the Forest Stewardship Council and the Marine Stewardship Council. The advantage for the buyer is that he or she does not have to make all the steps described under the single firm approach and legitimacy is gained by the overall label instead of the single company (Müller et al., 2009). In practice, for the retailer to purchase ecolabelled products (also from developing countries), the firm does not have to inspect all suppliers itself, but can expect to rely on a well established third party control of the supplier (Mamic, 2005). The existence of independent third parties also provides legitimacy and trust. This mechanism of reducing transaction costs with joint third party approaches has been developed in various ways and has also been penetrating in the mainstream of product channels, where market leaders have started creating their own value chain governance systems, sometimes separately, sometimes jointly with some competitors and in other cases sector wide.

Cross sectoral approaches: third generation. The third most recent form of sustainable supply chain governance goes beyond specific products and sectors and has been designed to be widely applicable in a uniform way. The most extensive example of this is Globalgap. It is a voluntary global partnership of market-based members, aiming at harmonizing world wide the application of good agricultural practice (GAP). It was initiated in I999 (as EurepGAP) by western European retailers in response to civil society and media attention to sustainability issues related to food consumption. It developed voluntary standards for the certification of agricultural products around the globe, to be used by retailers and their sourcing agencies in the contracting of producers of specific produce. Producers are audited for compliance on a yearly base.

The various forms of sustainable supply chain governance clarify two aspects that have hardly been addressed in the general analysis of value chains: first these varying forms of interaction, cooperation and compelling rules in the value chain are an instrument of competition, partly based on specific quality assets of the products (namely the environmental and socio-ethical performance of value chain partners), and second these forms of interaction and cooperation include other types of societal actor: apart from newly created non-profit governance institutions and their (for profit) auditing and control bodies, consumer NGOs, development NGOs and environmental NGOs also play diverse roles. At a distance governments play a role, partly in supporting these developments and by taking the existence and assumed effectiveness of these forms of sustainable supply chain governance as a point of departure for new forms of sustainability policy.

From the facts that firms and NGOs are the main initiators in this field, and that European governments are increasingly supporting this development, we can derive the observation that all practitioners (market, NGOs and governments) apply the basic assumption that business-to-business supply chain cooperation, geared by western consumer and civil society pressures, can be effective in improving environmental and social conditions in developing countries.

\section{An Outline of the Papers in the Special Issue}

This brings us to the relevant issue that we have taken as starting point for this special issue and a larger debate: what can we learn about the practices of sustainability through the market? In all its diverse forms and scales, what are the motives for and the impacts of sustainable supply chain management and governance? The issue is broad and can never be dealt with in one special issue. Yet we intend to have an ongoing debate in conferences and workshops.

In this special issue we present a number of studies addressing these questions from different perspectives. Some papers address firms active in the first generation of sustainable supply chain governance, both on the European side and on the side of developing countries, or the papers relate to the second and third generations. Another paper addresses the role of various stakeholders in sustainable supply chain governance. Perceptions both of western actors and of actors from developing countries are analysed. The question of which issues should actually be addressed and how this is determined is discussed in two articles. Two other articles explicitly take the perspective of the producers in developing countries and their appreciation and capabilities to respond to Europe based supply chain demands. 
We start from the European perspective. The next article in this special issue, by Laine and Laine, analyses how the World Shop movement, which started as a solidarity movement, is moving into a more commercial organization. Early approaches to organizing sustainability in the supply chain are challenged and different groups within the World Shop movement take different views on the preferred future development. In the context of growing supply of 'sustainable products', also by mainstream firms, reliability based upon trust, as was the initial mode, does not seem to be effective anymore. In this context the (struggle with) repositioning of the Finnish World Shops is exemplary for development in other western countries.

The third article, by Haake and Seuring, challenges the routine focus in identifying sustainability issue on major issues: the large loads of supplies and sustainability impacts connected to the core production process. They present various arguments for a more inclusive approach, also covering minor issues in sustainable supply chain management. Issues apparently small for one individual firm can very well be relevant, as the sum of all small impacts can still be substantial if analysed at a larger scale. This calls for a reorientation in the approaches for identification of issues to be addressed in sustainable supply chain management and sustainable supply chain governance.

The fourth article, by Muller, Vermeulen and Glasbergen, takes us to the interplay between various actors in global supply chain networks and analyses the perceptions and activities of NGOs and importers on the European side and of the government and producers on the South African side, addressing sustainability issues in the production, trade and consumption of fresh fruits. It connects the issues on the agenda of NGOs with the retailers' and importers' responses in creating business-to-business certification systems, and compares this with the regulative practice in South Africa and reports on an assessment of practices on South African farms. It illustrates the success of NGO activity in the sense of stimulating business uptake, but also shows a gap between western NGO perceptions and practices in the field.

The fifth article, by Schultze and Albertsmeier, focuses on certification of organic agricultural products in Latin America and analysis the producers' perceptions of western based certification systems. An increasing number of such sustainable supply chain governance systems address these producers. Reliability has been studied before from the perspective of consumers, but this article takes a new step by also analysing to what extent smallholders in countries such as Brazil and Costa Rica perceive the reliability of the promised benefits and the burden of administration and documentation.

The final article, by Ras and Vermeulen, takes us to an emerging economy, South Africa, and also analyses the take-up of business-to-business supply chain sustainability requirements by producers in the table grape production. It poses the question of which entrepreneurial qualities are needed to be able to compete on the growing international market for sustainable products. It discusses the sector wide implementation of various European sustainable supply chain governance systems and shows how various elements of 'entrepreneurship', including innovativeness and responsiveness, correlate with the improvement in environmental performance.

Sustainable supply chain management and governance will stay on the agenda, for companies, consumers, NGOs and even governmental agencies. The challenges of climate change, energy provision and creating wealth for an increasing world population will rather broaden the need for sustainability management and sustainable supply chain management and governance in the near future. We look forward to working with other researchers in the field on these relevant and interesting questions. These questions would include e.g. the following topics:

- Further empirical research on sustainable supply chain management and governance is very welcome. While a considerable number of related papers have been published, there are many open questions.

- Attempts for concept and theory formulation driving the field further and condensing and advancing first attempts made so far are demanded.

- Sustainability and business performance implications and outcomes of related corporate activities.

- Interaction among companies and stakeholders in the supply chain (both in the north and the south), assessing, e.g., issues of legitimacy, but also risk management issues.

- The allocation of costs and benefits of these governance approaches throughout the global supply chain.

- Innovation based approaches for redirecting supply chains towards sustainability. 
A further note also goes to the authorship of related papers, where we would like to encourage researchers from outside the western part of the world to be more active in related research. If we look at the academic literature, it is still dominated by writers from North America and Europe. Developing countries' scholars would be very welcome as they offer the chance of bringing in a perspective closer to companies and other supply chain actors in developing countries.

\section{Acknowledgements}

Thanks to all our reviewers, P. Beske, V. Bitzer, F. Ciliberti, V. Gozes dos Santos, R. Meijer, P. Rao, H. Schulze, M. Sigala, A. Smit, H. Walker and M. Walther, for their constructive and critical comments, and to the participants in the (annual) special track during the I4th International Sustainable Development Research Conference, 2008, in New Delhi, India.

\section{References}

Bitzer V, Francken M, Glasbergen P. 2008. Intersectoral partnerships for a sustainable coffee chain: really addressing sustainability or just picking (coffee) cherries? Global Environmental Change I8: 27I-284.

Chouinard Y, Brown MS. I997. Going organic: converting Patagonia's cotton product line. Journal of Industrial Ecology I: II7-I29.

Davies IA. 2007. The eras and participants of fair trade: an industry structure/stakeholder perspective on the growth of the fair trade industry. Corporate Governance 7(4): 455-470.

de Groene A, Hermans M. I998. Economic and other implications of integrated chain management: a case study. Journal of Cleaner Production 6: I99-2II.

Goldbach M, Seuring S, Back S. 2003. Co-ordinating sustainable cotton chains for the mass market: the case of the German mail-order business OTTO. Greener Management International 43: 65-78.

Guinee JB. 2002. Handbook on Life Cycle Assessment: Operational Guide to the ISO Standards. Kluwer: Dordrecht.

Heijungs R, Guinee JB. I992. Environmental Life Cycle Assessment of Products. Centre of Environmental Science: Leiden.

Ims KJ, Jakobsen OD. 2006. Cooperation and competition in the context of organic and mechanic worldviews - a theoretical and case based discussion. Journal of Business Ethics 66: 19-32.

Kessler JJ, Romijn B, Pistorius R. 2003. Reciprocity in Sustainable Development. Royal Tropical Institute (KIT): Amsterdam.

Kilian B, Pratt L, Jones C, Villalobos A. 2004. Can the private sector be competitive and contribute to development through sustainable agricultural business? A case study of coffee in Latin America. International Food and Agribusiness Management Review 7: 2I-45.

Kogg B. 2003. Greening a cotton-textile supply chain: a case study of the transition towards organic production without a powerful focal company. Greener Management International 43: 53-64.

Mamic I. 2005. Managing global supply chain: the sports footwear, apparel and retail sectors. Journal of Business Ethics 59(I): 8I-I00.

Müller M, Gomes dos Santos V, Seuring S. 2009. The contribution of environmental and social standards towards ensuring legitimacy in supply chain governance. Journal of Business Ethics. DOI: I0.1007/sio55I-008-0013-9

Parrish BD, Luzadis VA, Bentley WR. 2005. What Tanzania's coffee farmers can teach the world: a performance-based look at the fair tradefree trade debate. Sustainable Development I3: I77-I89.

Raynolds LT, Murray D, Heller A. 2007. Regulating sustainability in the coffee sector: a comparative analysis of third-party environmental and social certification initiatives. Agriculture and Human Values 24: 147-163.

Schaltegger S. 2002. A framework for ecopreneurship: leading bioneers and environmental managers to ecopreneurship. Greener Management International $45-58$.

Seuring S. 2004. Integrated chain management and supply chain management - comparative analysis and illustrative cases. Journal of Cleaner Production I2(8-10): 1059-I07I.

Seuring S, Müller M. 2008a. Core issues in sustainable supply chain management - a Delphi study. Business Strategy and the Environment I7 (8): $455-466$.

Seuring S, Müller M. 2008b. From a literature review to a conceptual framework for sustainable supply chain management. Journal of Cleaner Production I6(I5): I699-I7Io.

Vermeulen WJV. 2008. Sustainable global product chains: actors, systems and mechanisms at three levels. 14th Annual International Sustainable Development Research Conference, September 21-23, 2008. India Habitat Center: New Delhi.

Vermeulen WJV, Ras P. 2006. The challenge of greening global product chains: meeting both ends. Sustainable Development I4: $245^{-256 .}$ 